\title{
Man/Cel5B, a Bifunctional Enzyme Having the Highest Mannanase Activity in the Hyperthermic Environment
}

\author{
Beenish Sadaqat ${ }^{\dagger}$, Chong Sha ${ }^{\dagger}$, Parveen Fatemeh Rupani, Hongcheng Wang, \\ Wanbing Zuo and Weilan Shao*
}

Biofuels Institute, School of the Environment and Safety Engineering, Jiangsu University, Zheniiang, China

\section{OPEN ACCESS}

Edited by:

Noha M. Mesbah,

Suez Canal University, Egypt

Reviewed by:

Wenming Zhang,

Nanjing Tech University, China

Jin-Song Gong,

Jiangnan University, China

Samir Bejar

Centre of Biotechnology of Sfax,

Tunisia

*Correspondence:

Weilan Shao

weilanshao@foxmail.com

${ }^{\dagger}$ These authors have contributed equally to this work

Specialty section:

This article was submitted to Industrial Biotechnology,

a section of the journal

Frontiers in Bioengineering and

Biotechnology

Received: 04 December 2020

Accepted: 25 February 2021

Published: 16 March 2021

Citation:

Sadaqat B, Sha C, Rupani PF, Wang H, Zuo W and Shao W (2021)

Man/Cel5B, a Bifunctional Enzyme

Having the Highest Mannanase

Activity in the Hyperthermic

Environment.

Front. Bioeng. Biotechnol. 9:637649.

doi: 10.3389/fbioe.2021.637649
Thermotoga maritima (Tma) contains genes encoding various hyperthermophilic enzymes with great potential for industrial applications. The gene TM1752 in Tma genome has been annotated as cellulase gene encoding protein Cel5B. In this work, the gene TM1752 was cloned and expressed in Escherichia coli, and the recombinant enzyme was purified and characterized. Interestingly, the purified enzyme exhibited specific activities of 416 and $215 \mathrm{U} / \mathrm{mg}$ on substrates galactomannan and carboxy methyl cellulose, which is the highest among thermophilic mannanases. However, the putative enzyme did not show sequence homology with any of the previously reported mannanases; therefore, the enzyme Cel5B was identified as bifunctional mannanase and cellulase and renamed as Man/Cel5B. Man/Cel5B exhibited maximum activity at $85^{\circ} \mathrm{C}$ and $\mathrm{pH} 5.5$. This enzyme retained more than $50 \%$ activity after $5 \mathrm{~h}$ of incubation at $85^{\circ} \mathrm{C}$, and retained up to $80 \%$ activity after incubated for $1 \mathrm{~h}$ at $\mathrm{pH} 5-8$. The $\mathrm{K}_{m}$ and $\mathrm{V}_{\max }$ of Man/Cel5B were observed to be $4.5 \mathrm{mg} / \mathrm{mL}$ galactomannan and $769 \mathrm{U} / \mathrm{mg}$, respectively. Thin layer chromatography depicted that locust bean gum could be efficiently degraded to mannobiose, mannotriose, and mannooligosaccharides by Man/Cel5B. These characteristics suggest that Man/Cel5B has attractive applications for future food, feed, and biofuel industries.

Keywords: hyperthermophilic $\beta$-mannanase, bifunctional mannanase, highest mannanase activity, mannooligosaccharides, Thermotoga maritima

\section{INTRODUCTION}

Mannan is a complex biopolymer, composed of mannose residues that are linked together by $\beta-1,4$ linkages named as pure mannan, or the polysaccharide may be a mixture of $\beta-1,4$-Dmannose and $\beta-1,4-\mathrm{D}$-glucose units termed as glucomannan. These mannan and glucomannan polysaccharides may also be linked to $\alpha$-1,6-linked galactose residues and the corresponding polysaccharides are called as galactomannan and galactoglucomannan, respectively. Generally, $1,4-\beta$-D-Mannan mannanohydrolase or endo-1,4- $\beta$-mannosidase (EC 3.2.1.78) is called as $\beta$ mannanase, which causes random cleavage of $\beta$-mannosidic linkages in mannan backbone (Zhu et al., 2020). Depending on sequence similarity, mannanases from various sources, such as bacteria, 
fungi, and plants, have been categorized within glycoside hydrolase families 5, 26, 113, and 134 within carbohydrate-active database (Ghosh et al., 2013).

$\beta$-mannanase plays an essential role in the degradation of lignocellulosic biomass as $\beta$-mannan is the principal component of hemicellulose in soft woods. $\beta$-mannanase has also been employed for the degradation of mannan in the cell wall of palm kernel cake for ethanol or biobutanol production (Cerveró et al., 2010; Shukor et al., 2016). In addition, it can degrade mannan-rich agricultural crop residues, such as locust bean gum (LBG) and guar gum into mannooligosaccharides (MOS) which have numerous health benefits (Katrolia et al., 2013). $\beta$-mannanase is extensively used in the paper/pulp, food, and feed industries, particularly in poultry feeds and prebiotic food supplements to decrease the immunogenic effect of mannan polymers, clarify fruit juices, and extract of oil from copra and detergent (Kaira et al., 2016; Singh et al., 2019). In these industries, thermostable enzymes are preferentially used (Dhawan et al., 2016; Li and Nie, 2016) due to their robustness and enhanced rate of hydrolysis (Katsimpouras et al., 2016; Niu et al., 2017). Moreover, thermozymes offer unique features such as high pH, solvent concentrations (Liu et al., 2019), and resistance to chemical denaturation (Akram et al., 2018), and they could reduce contamination from unwanted microbes (Ebaid et al., 2019). Thermozymes also exhibit low fluid viscosity, and high saccharification and production yield (Sarmiento et al., 2015), thereby improving the cost-effectiveness of the bioprocess (Arora et al., 2015).

Thermophiles and hyperthermophiles are excellent sources of thermozymes for potential applications in industries and molecular biology. In particular, Thermotoga maritima (Tma), an anaerobic rod-shaped bacterium, with an optimal growth temperature of $\sim 80^{\circ} \mathrm{C}$ is considered an invaluable source of industrially important thermozymes (Myung et al., 2010). In fact, the genes TM1227 and 1751 from Tma encoded $\beta$ mannanases, have specific activities of up to 90 and $69 \mathrm{U} / \mathrm{mg}$ on galactomannan, respectively (Chhabra et al., 2002).

Considering the widespread usage of $\beta$-mannanases in different industries, there is a dire need to identify hyperthermophilic $\beta$-mannanases with high specific activity and thermostability. TM1752 (TM_RS08910) in the Tma genome encodes a putative endoglucanase Cel5B, belonging to the GH5 family. In this work, high level expression of gene TM1752 was attained in Escherichia coli using heat shock pHsh vector. Further, the recombinant protein was purified and biochemically characterized. To assess the possible application of the purified enzyme in the food/feed industry, the enzyme was used for the production of MOS from LBG which was evaluated by thin layer chromatography (TLC) analysis.

\section{MATERIALS AND METHODS}

\section{Chemicals, Strains, and Plasmid}

Locust bean gum, galactomannan extracted from the seeds of a locust bean tree with mannose: galactose ratio of approximately 4:1, was purchased from Adamas (Pennsylvania
Avenue, Washington, DC). Xylan, avicel, and carboxy methyl cellulose (CMC) were purchased from Merck (Singapore), and lichenan was purchased from Megazyme (Ireland). All other chemicals used in this study were of analytical grade and obtained from Sinopharm Chemical Reagent Co., Ltd. (China).

The Tma MSB8 (ATCC 43589) strain was acquired from the American Culture Collection (Manassas, Virginia), and grown in the Thermotoga basal medium (TMB) supplemented with $0.5 \%$ glucose (Jiang et al., 2006). Host E. coli JM109 was purchased from Promega Corporation (Madison, WI, United States), whereas the pHsh vector was provided by Shine E Biotech (Nanjing, China).

\section{Cloning of TM1752 Gene in Expression Plasmid pHsh}

To amplify TM1752 gene (accession no. TM_RS08910), PCR was carried out using the genomic DNA of Tma MSB8 as a template. Primers were synthesized based on the open reading frame sequence with forward and reverse sequences TM1752F/TM1752R as follows: 5'-AATAACACCATTCCAAGATGG-3'/5'-GTATCTAGATTCA ATGCTATCTCCTCCTAA-3'. pHshF/pHshR: 5'-GTATCTAGA CACCACCACCACCACCACTAA-3' $/ 5^{\prime}$ CATGGGTATATCTCC TTCTTGTC-3'. The primers were used to amplify the whole vector "pHsh" by reverse PCR (italic means the starting codon, and the underline indicates the XbaI recognition site). The amplified DNA fragments and the pHsh vector were digested using the restriction enzyme XbaI (Takara, the $5^{\prime}$ terminus is the blunt end and the $3^{\prime}$ teminus is the cohesive end), and purified by gel electrophoresis using Axygen AxyPrep DNA Gel Recovery Kit (Corning, NY, United States) according to the manufacturer's instructions, and then ligated together using Takara Bio DNA Ligation Kit (Kyoto, Japan). The recombinant DNA was transformed into E. coli JM109, and the transformed E. coli cells were spread-plated onto Luria-Bertani (LB) solid agar plates supplemented with $100 \mu \mathrm{g} / \mathrm{mL}$ ampicillin. These plates were then kept at $30^{\circ} \mathrm{C}$ overnight. The positive transformants for the expression plasmid pHsh-TM1752 were selected for PCR and sequence verification.

\section{Gene Expression and Protein Purification}

The recombinant plasmid was transformed into E. coli JM109 using the heat-shock method. Briefly, the transformed cells were grown on LB agar plates and incubated at $30^{\circ} \mathrm{C}$ for $24 \mathrm{~h}$. One colony was transferred to $200 \mathrm{~mL} \mathrm{LB}$ media supplemented with $100 \mu \mathrm{g} / \mathrm{mL}$ ampicillin and incubated at $30^{\circ} \mathrm{C}$ with shaking at $200 \mathrm{rpm}$ up to an $\mathrm{OD}_{600}$ of 0.8 . Subsequently, the cells were incubated at $42^{\circ} \mathrm{C}$ for $8 \mathrm{~h}$ for protein production.

Next, the cells were harvested by centrifugation at $7000 \times g$ for $20 \mathrm{~min}$ at $4^{\circ} \mathrm{C}$, the supernatant was discarded and the obtained cell pellets were resuspended in the binding buffer $(5 \mathrm{mM}$ imidazole, $0.5 \mathrm{M} \mathrm{NaCl}$, and $20 \mathrm{mM}$ Tris) at $\mathrm{pH}$ 8.0. Then, the cells were disrupted by sonication for $30 \mathrm{~min}$ ( $9 \mathrm{~s}$ on and $6 \mathrm{~s}$ off). The obtained cytoplasmic extract was subjected to heat treatment at $70^{\circ} \mathrm{C}$ for $20 \mathrm{~min}$ and centrifuged at $10,000 \times g$ for $30 \mathrm{~min}$ at $4^{\circ} \mathrm{C}$ to remove denatured protein and cell debris. The supernatant 
was loaded onto the immobilized nickel-affinity column (GE) equilibrated with the binding buffer, and eluted using the elution buffer (500 mM imidazole, $0.5 \mathrm{M} \mathrm{NaCl}$, and $20 \mathrm{mM}$ Tris- $\mathrm{HCl}$ ) at $\mathrm{pH} 8$, separated by sodium dodecyl sulfate-polyacrylamide gel electrophoresis (SDS-PAGE), and dialyzed against phthalateimidazole (PI) buffer at pH 6.8 for subsequent analysis. The purified enzyme was conserved in the stock solution $(25 \mathrm{mM}$ pH 6.8 of PI buffer, $20 \%$ glycerol, and $0.02 \%$ sodium azide). Protein concentration of the purified enzyme was determined by measuring the absorbance at $280 \mathrm{~nm}$ (A280).

\section{Enzyme Assay and Substrate Specificity}

The activity of the recombinant enzyme was determined using the 4-hydroxybenzoic acid hydrazide method (Lever, 1972). The reaction mixture contained $100 \mu \mathrm{L}$ of $0.5 \%(w / v)$ substrate in water, $95 \mu \mathrm{L}$ of PI buffer ( $25 \mathrm{mM}, \mathrm{pH} 6.0$ ), and $5 \mu \mathrm{L}$ of purified enzyme, was incubated at the target temperature for $5 \mathrm{~min}$. The reaction was stopped by adding $600 \mu \mathrm{L}$ of 4-hydroxybenzoic acid hydrazide and boiling for $10 \mathrm{~min}$. The reaction mix was cooled on ice, and the absorbance was measured at $410 \mathrm{~nm}$. One unit (U) of enzyme activity is defined as the quantity of enzyme required to release $1 \mu \mathrm{mol}$ of reducing sugar in $1 \mathrm{~min}$. All enzyme assays were performed in triplicate, and data were reported as the mean \pm standard deviation.

To examine the specificity of the recombinant enzyme toward different substrates, the enzyme was incubated with LBG, CMC, avicel, xylan, lichenan, and starch $(0.5 \%, w / v)$ at $85^{\circ} \mathrm{C}$ and $\mathrm{pH} 5.5$. The reaction mixture also contained $1 \mathrm{mM} \mathrm{CoCl}_{2}$.

\section{Sequence Analysis}

The amino acid sequence of TM1752 was compared with that of proteins in the gene bank via BLAST analysis on the NCBI server. Multiple sequence alignment was performed using Clustal W (1.83), as displayed by Escript. The molecular mass of recombinant enzyme was predicted using the Expasy bioinformatics resource portal.

\section{Biochemical Charaterization of Purified Enzyme}

The optimum temperature of the purified enzyme was determined at various temperatures from 60 to $90^{\circ} \mathrm{C}$ using assay conditions as mentioned earlier in $25 \mathrm{mM}$ PI buffer at $\mathrm{pH}$ 6.8. Thermostability was determined by incubating the enzyme at 85,90 , and $95^{\circ} \mathrm{C}$ without substrate in the PI buffer $(\mathrm{pH} 6.8)$ for up to $5 \mathrm{~h}$. The incubated enzyme samples were taken after every hour, and residual activity was determined under standard assay conditions as described earlier.

The optimum $\mathrm{pH}$ of the recombinant enzyme was examined at $\mathrm{pH}$ ranging from $\mathrm{pH} 4.0$ to 7.5 , using $25 \mathrm{mM}$ PI buffer at the optimal temperature. $\mathrm{pH}$ stability was evaluated by calculating the residual enzyme activity at optimum conditions after incubation in PI buffer of $\mathrm{pH}$ 3.0-8.0 at optimal temperature for $1 \mathrm{~h}$ without substrate.

The impact of detergents and oxidizing and reducing agents, including SDS, Tween-80, Triton X-100, CTAB, hydrogen peroxide, ammonium persulfate, Ascorbic acid, and EDTA (at a final concentration of $1 \%$ ), on the enzyme activity of the recombinant enzyme was examined by pre-incubating the enzyme in the presence of these preparations for $30 \mathrm{~min}$. The remaining enzymatic activities were estimated at optimum temperature and $\mathrm{pH}$. The activities of the purified enzyme without any additives and pre-incubated at same conditions were recorded as $100 \%$ activity.

Furthermore, the influence of $\mathrm{Cu}^{2+}, \mathrm{Ni}^{2+}, \mathrm{Co}^{2+}, \mathrm{Mn}^{2+}$, $\mathrm{Ca}^{2+}, \mathrm{Cr}^{3+}, \mathrm{Zn}^{2+}, \mathrm{Mg}^{2+}$, and $\mathrm{Sr}^{2+}$ ions was examined by adding $1 \mathrm{mM}$ of each ion to the reaction mixture. Then, enzyme activity was determined at the optimal temperature and $\mathrm{pH}$, and recorded as the percent of enzyme activity observed when no metal ions were added to the reaction system. The metal with the most significant effect on enzyme activity was selected, and its optimum concentration required to increase enzyme activity under optimal reaction conditions was determined. To this end, the enzyme activity was determined at increasing concentration (0.0-2.0 mM) of selected metal ion. The enzyme activity was determined under optimal reaction conditions.

Kinetic parameters were calculated by observing enzyme activity in increasing substrate concentrations i.e., 0.5$15.0 \mathrm{mg} / \mathrm{mL}$ and $1 \mathrm{mM} \mathrm{Co}{ }^{2+}$. The Michaelis-Menten constant $\left(\mathrm{K}_{m}\right)$ and the maximum rate of reaction $\left(\mathrm{V}_{\text {max }}\right)$ were determined using the Michaelis-Menten (V vs. [S]) and Lineweaver-Burk plots (1/V vs. $1 /[\mathrm{S}])$.

\section{Hydrolysis Products Analysis}

Thin layer chromatography was employed for the examination of sugar products liberated in the hydrolysis of LBG by recombinant enzyme. In this regard, $100 \mu \mathrm{L}$ of LBG $(0.5 \%)$ dissolved in PI buffer ( $\mathrm{pH} 5.5)$ and $100 \mu \mathrm{L}$ purified enzyme $(0.364 \mathrm{mg} / \mathrm{mL})$ were mixed together and incubated at optimum temperature for 15 , 30,45 , and $60 \mathrm{~min}$. Then, the mixture was boiled for $10 \mathrm{~min}$, and centrifuged at $7000 \times g$ for $5 \mathrm{~min}$, and the supernatant was frozen till volume reached $10 \mu \mathrm{L}$.

The TLC plate (Silica gel-coated aluminum plate, Merck, Germany) was spotted with $1.0 \mu \mathrm{L}$ of concentrated hydrolyzed sample and standards of mannose, mannobiose and mannotriose. The concentration of the standards was $1 \mathrm{mg} / \mathrm{mL}$ in $\mathrm{ddH}_{2} \mathrm{O}$. The plate was developed using acetonitrile: water $(65: 35 \mathrm{v} / \mathrm{v})$ as the mobile phase. After drying, the plate was stained with $0.3 \% \mathrm{~N}-(1-$ napthyl)ethylenediamine dihydrochloride dissolved in methanol containing $5 \% \mathrm{H}_{2} \mathrm{SO}_{4}$ (Bounias, 1980) to detect the sugars.

\section{RESULTS}

\section{Gene Expression and Enzyme Purification}

The TM1752 gene was successfully amplified from genomic DNA of Tma via PCR, ligated with vector $\mathrm{pHsh}$ and transformed into E. coli using heat shock method. The gene was expressed to a relatively high level in $\mathrm{pHsh}$ expression system (Figure 1). The recombinant enzyme was purified via subsequent heat treatment and Nickle affinity chromatography of the soluble fraction of cells obtained after sonication. The enzyme was purified to near homogeneity as depicted in SDS-PAGE analysis (Figure 1). The 


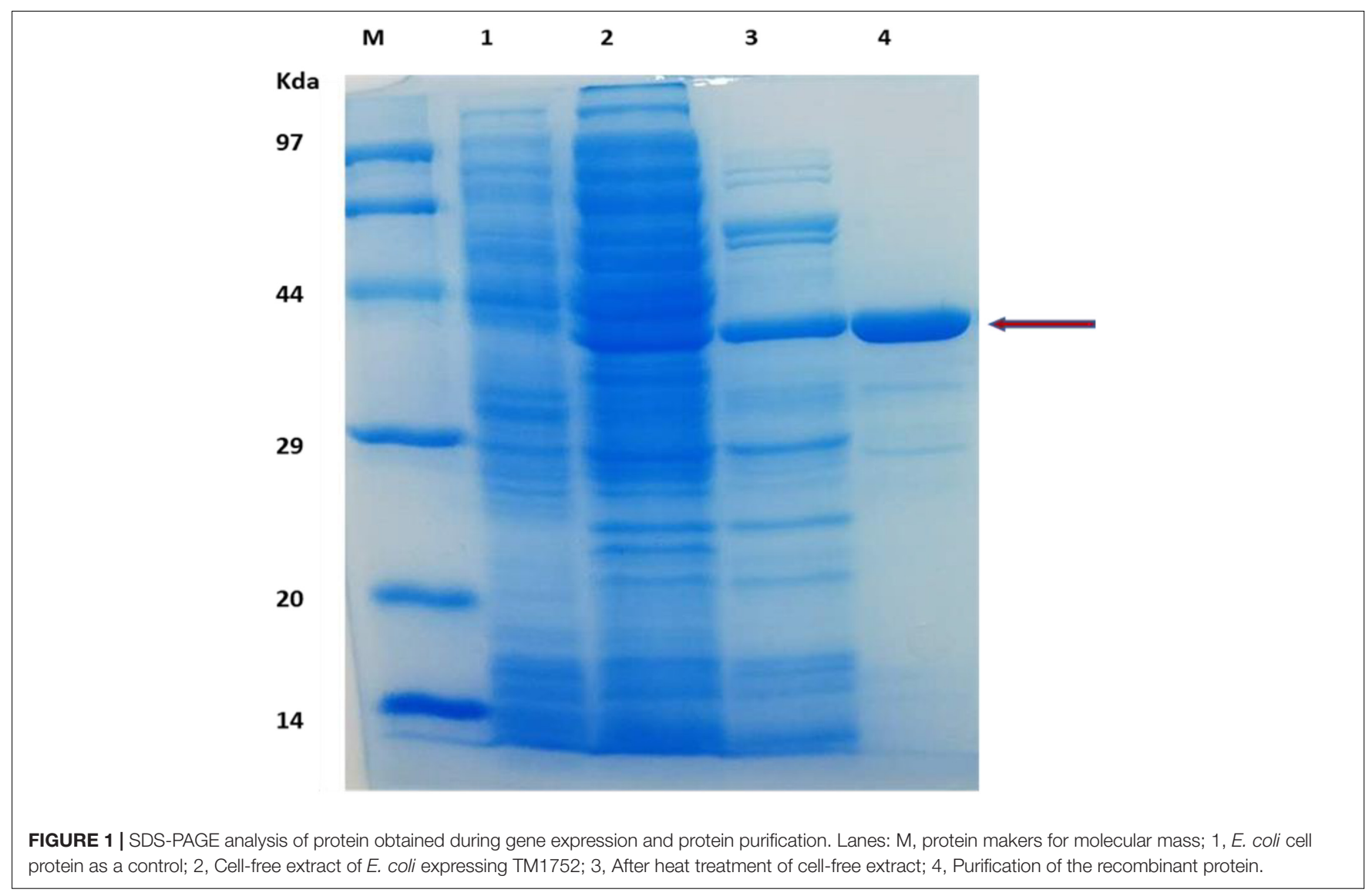

purified enzyme exhibited a molecular mass of approximately $38 \mathrm{kDa}$ in SDS-PAGE, which was in agreement with the prophesied (ExPasy online portal) molecular mass of $39 \mathrm{kDa}$.

\section{Substrate Specificity of Recombinant Enzyme}

The specificity of the purified enzyme with different carbon sources was examined by incubating the enzyme with LBG, CMC, avicel, lichenan, starch, and xylan. These substrates vary in their backbone composition and the type of glycosidic linkages. The purified protein exhibited the highest activity of $416 \mathrm{U} / \mathrm{mg}$ for LBG (Table 1), a galactomannan. Among glucan-based

TABLE 1 | Substrate specificity of the purified protein from expression plasmid pHsh-TM1752.

\begin{tabular}{llc}
\hline Substrate & $\begin{array}{l}\text { Backbones (type of bond or } \\
\text { linkage) }\end{array}$ & $\begin{array}{c}\text { Specific } \\
\text { activity } \\
\text { (U/mg) }\end{array}$ \\
\hline $\begin{array}{l}\text { Locust bean gum } \\
\text { Carboxy methyl }\end{array}$ & $\begin{array}{l}\beta-1,4-\text {-glycosidic bond (mannose) } \\
\text { cellulose }\end{array}$ & 416 \\
Avicel & $\beta-1,4$-glycosidic bond (glucose) & 215 \\
Starch & $\alpha-1,4-$ glycosidic bond (glucose) & 1.42 \\
Xylan & $\beta-1,4-$ glycosidic bond (xylose) & 0 \\
Lichenan & $\beta-1,3-1,4-$ glycosidic bond (glucose) & 0
\end{tabular}

substrates, the strongest enzyme activity for CMC (215 U/mg) and a very low activity of 1.42 for Avicel were observed. The specific activity of the purified enzyme for lichenan was only $0.88 \mathrm{U} / \mathrm{mg}$. The enzyme however didn't show any activity for starch and xylan.

\section{Bioinformatic Analysis of TM1752 Gene Product}

The deduced amino acid sequence of TM1752 gene was paralleled with protein sequenes of already-characterized proteins using BLAST. According to the amino acid homology search (Figure 2), Cel5B did not show similarity with any other $\beta$-mannanase in the GenBank. It demonstrated highest identity (99.7\%) with endoglucanase from Tma (accession number AHD18354.1). The amino acid sequence homology with other endoglucanases were 68.6, 58.6, and 53.9\% from Dictyoglomus thermophilum (accession number HEU67460.1), D. thermophilum (accession number WP_012547750.1), and Anaerolinea thermolimosa (accession number WP_062192228.1), respectively. These results indicate that Cel5B is principally a novel mannanase as it exhibited high specific activity for LBG and did not show sequence identity with already reported mannanases. Meanwhile, it had a sequence of up to $68.6 \%$ homology with the cellulases from some other thermophilic species other than Tma, and showed considerable specific activity for $\mathrm{CMC}$ as well. Therefore, the enzyme is a novel bifunctional 


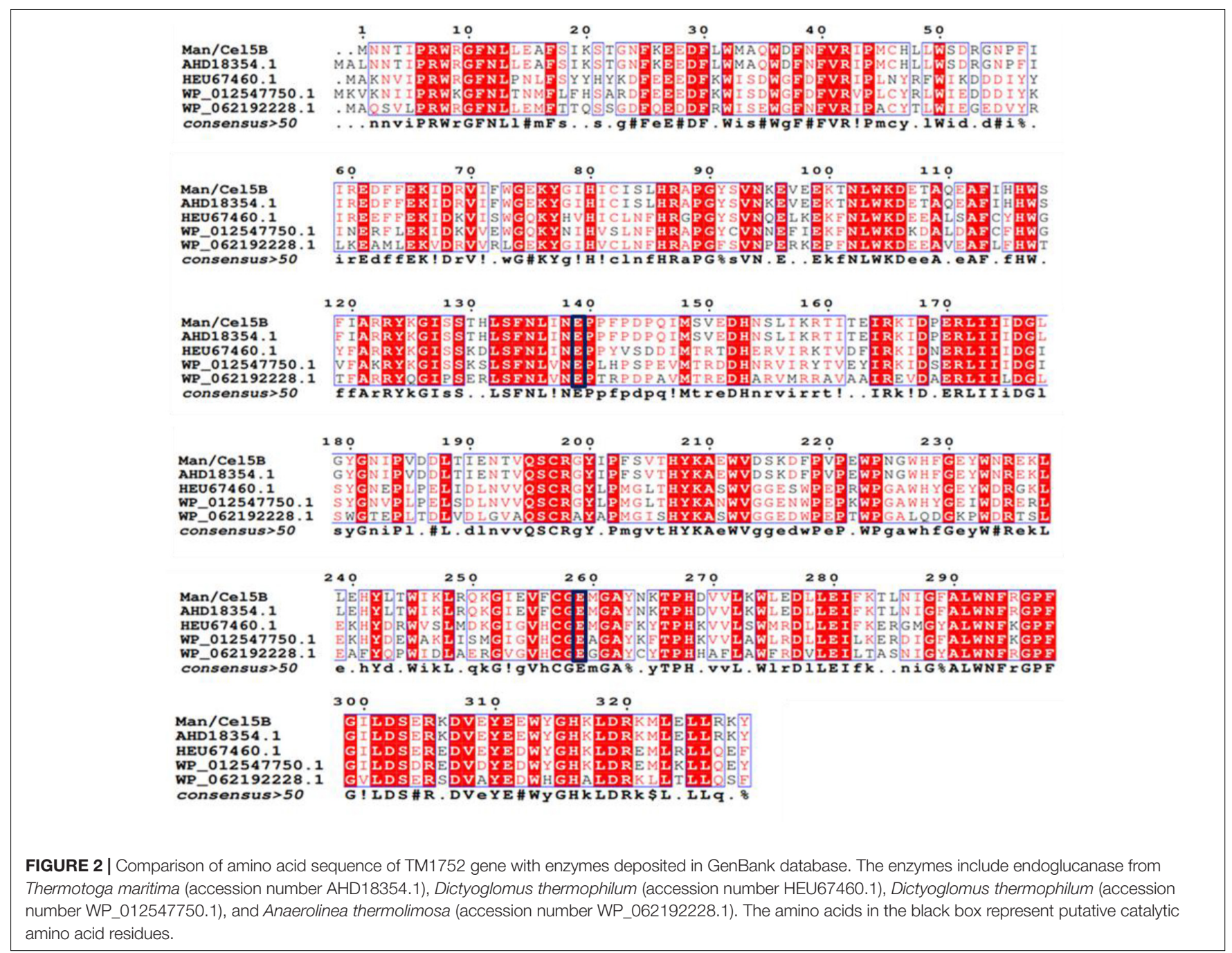

mannanase/cellulase that should be renamed as Man/Cel5B. Besides, the amino acid sequence analysis predicted that Glu 139 and Glu 259 worked as acid/base and nucleophile residues, respectively during hydrolysis of substrate by Man/Cel5B.

\section{Catalytic and Kinetic Properties of Man/Cel5B}

Man/Cel5B exhibited enzyme activity over the range of studied temperature. Its activity reached the highest at $85^{\circ} \mathrm{C}$ and drastically reduced at $90^{\circ} \mathrm{C}$ (Figure 3A). Thermostability experiments specified that Man/Cel5B retained $>55 \%$ of the activity after $5 \mathrm{~h}$ of pre-incubation in the absence of substrate at $85^{\circ} \mathrm{C}$ and $>50 \%$ of the enzyme activity after $4 \mathrm{~h}$ at $90^{\circ} \mathrm{C}$ ( $\mathrm{pH}$ 6.8) (Figure 3B). The purified enzyme exhibited more than $70 \%$ of activity between $\mathrm{pH} 5.0$ and $\mathrm{pH} 6.0$ with an optimum $\mathrm{pH}$ of 5.5 (Figure $4 \mathbf{A}$ ). In addition, after pre-incubation for $1 \mathrm{~h}$ in PI buffer having $\mathrm{pH}$ values between 3.0 and $8.0\left(85^{\circ} \mathrm{C}\right)$, Man/Cel5B retained $>85 \%$ of the initial activity at $\mathrm{pH}$ range $5.0-$ 7.0 (Figure 4B). The highest stability of Man/Cel5B was observed at $\mathrm{pH} 6.0$ where the enzyme retained $96 \%$ of its initial activity.
The influence of various chemicals on the activity of Man/Cel5B are summarized in Table 2. Among the tested chemicals, Tween 80 enhanced enzyme activity by up to $137 \%$. Hydrogen peroxide, ascorbic acid and ammonium persulfate similarly boosted its activity to 112,109 , and $102 \%$, respectively (Table 2). On the other hand, EDTA slightly reduced enzyme activity to $94 \%$. Furthermore, only SDS and CTAB inhibited the enzyme activity to a greater extent, that is 49 and $53 \%$, respectively.

The influence of ionic metals on Man/Cel5B activity was examined by determining the mannanase activity in the presence of $1 \mathrm{mM}$ metal ion in the reaction mixture (Figure 5A). According to the differential analysis, $\mathrm{Co}^{2+}$ significantly enhanced the enzyme activity to $191 \%$ as compared to control (activity when no ion was added). However, the enzyme activity was drastically reduced to $20 \%$ of its initial activity in the presence of $\mathrm{Cu}^{2+}$, thereby indicating its inhibitory effect on Man/Cel5B. In addition, metals like $\mathrm{Ni}^{2+}$ and $\mathrm{Zn}^{2+}$ exhibited slight inhibition of enzyme activity by about $15 \%$. The metal ion requirement for achieving high activity was further examined in the presence of increasing $\mathrm{Co}^{2+}$ concentrations. The optimum concentration 

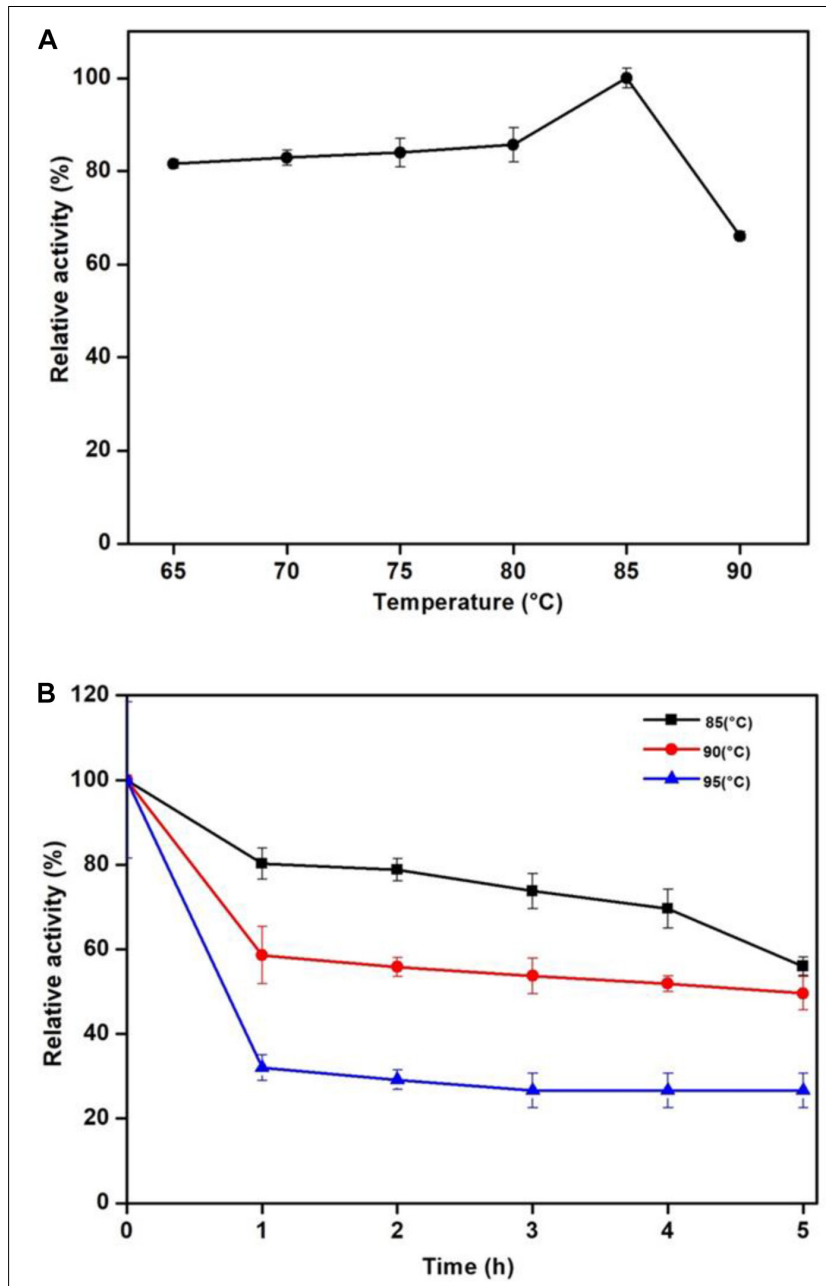

FIGURE 3 | Effect of temperature on the mannanase activity of Man/Cel5B. (A) Dependence of mannanase activity on the temperature.

(B) Thermostability of Man/Cel5B. The enzyme $(0.364 \mathrm{mg} / \mathrm{mL})$ was incubated at temparatures 80,85 , and $90^{\circ} \mathrm{C}$ for $5 \mathrm{~h}$ in the absence of substrate, and residual activity was examined at optimal conditions.

of $\mathrm{Co}^{2+}$ for Man/Cel5B activity was between 1.0 and $1.5 \mathrm{mM}$ (Figure 5B), as the enzyme activity increased to approximately $200 \%$, whereas the enhancement of Man/Cel5B activity started reducing when $\mathrm{Co}^{2+}$ concentration reached $2 \mathrm{mM}$ or higher. The $\mathrm{K}_{m}$ and $\mathrm{V}_{\text {max }}$ values were evaluated at optimum conditions of temperature and $\mathrm{pH}$ with $1 \mathrm{mM} \mathrm{Co}^{2+}$ in the increasing concentration of LBG. $\mathrm{K}_{m}$ and $\mathrm{V}_{\max }$ were found to be $4.5 \mathrm{mg} / \mathrm{mL}$ and $769 \mathrm{U} / \mathrm{mg}$, respectively.

\section{Analysis of LBG Hydrolysis Products}

The time course enzymatic hydrolysis products of LBG were analyzed, and the produced mannobiose, mannotriose, and MOS were detected on TLC plates (Figure 6). LBG was not hydrolyzed into mannose, which indicates Man/Cel5B cleaves internal bonds in the mannose back bone. The production of mannobiose, mannotriose, and MOS upon degradation of LBG indicates that Man/Cel5B can be used for the hydrolysis of
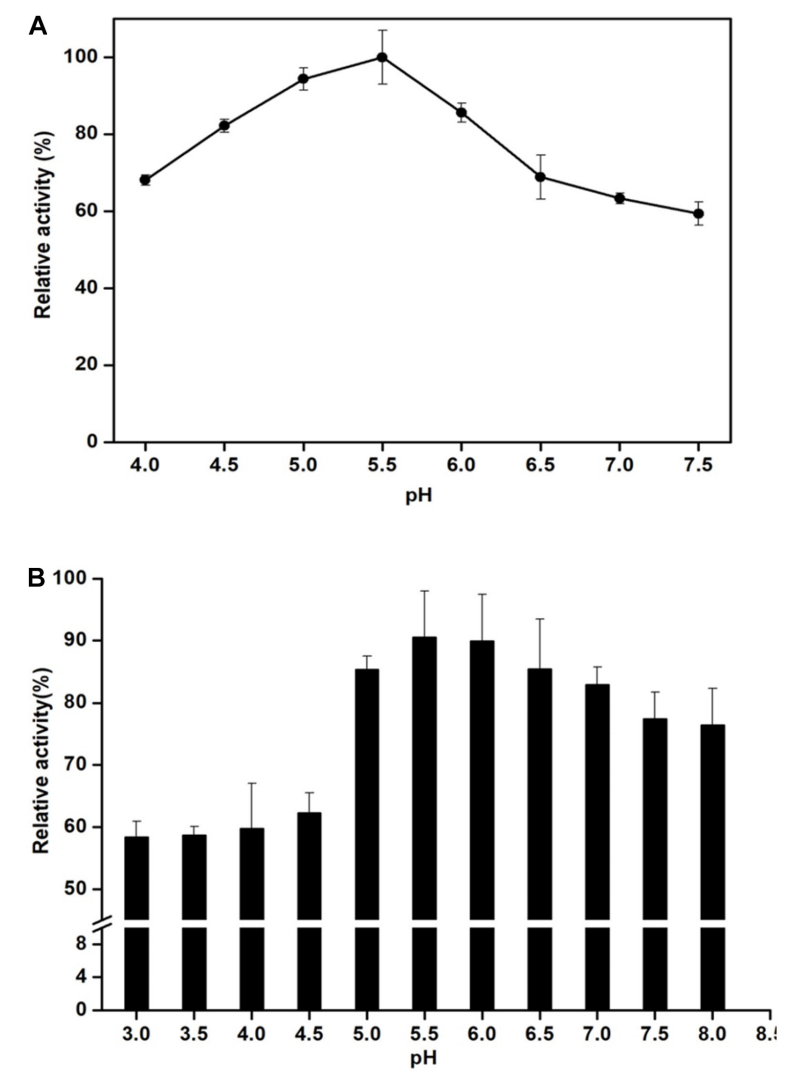

FIGURE 4 | Effect of $\mathrm{pH}$ on the mannanase activity of Man/Cel5B.

(A) Determination of $\mathrm{pH}$ optimum. Enzyme activity was determined in Phthalate-Imidazole (PI) buffer with pH ranging between 4 and 8. (B) Enzyme stability at various $\mathrm{pH}$. The enzyme was incubated in $\mathrm{PI}$ buffer with different $\mathrm{pH}$ values at a range of 4-7.5 for $1 \mathrm{~h}$ in the absence of substrate, and residual activity was measured by adding substrate dissolved in the buffer at $\mathrm{pH} 5.5$.

TABLE 2 | Effect of detergents, oxidizing agents, reducing agents, and chelating agents on the Man/Cel5B activity.

\begin{tabular}{|c|c|c|}
\hline Reagents & Concentration & Relative activity (\%) \\
\hline Control & & $100 \%$ \\
\hline Detergents & $1 \%(w / v)$ & \\
\hline SDS & $1 \%(w / v)$ & 43 \\
\hline CTAB & $1 \%(w / v)$ & 59 \\
\hline Tween-80 & $1 \%(v / v)$ & 137 \\
\hline Triton X 100 & $1 \%(v / V)$ & 74 \\
\hline \multicolumn{3}{|l|}{ Oxidizing agents } \\
\hline Ammonium persulfate & $1 \%(w / V)$ & 103 \\
\hline Hydrogen peroxide & $1 \%(w / V)$ & 113 \\
\hline \multicolumn{3}{|l|}{ Reducing agent } \\
\hline Ascorbic acid & $1 \%(v / v)$ & 110 \\
\hline \multicolumn{3}{|l|}{ Chelating agent } \\
\hline EDTA & $1 \%(w / v)$ & 94 \\
\hline
\end{tabular}

commercially available LBG for the production of MOS as well as the hydrolysis of mannan in plant materials such as soybean meal or coffee bean powder. 


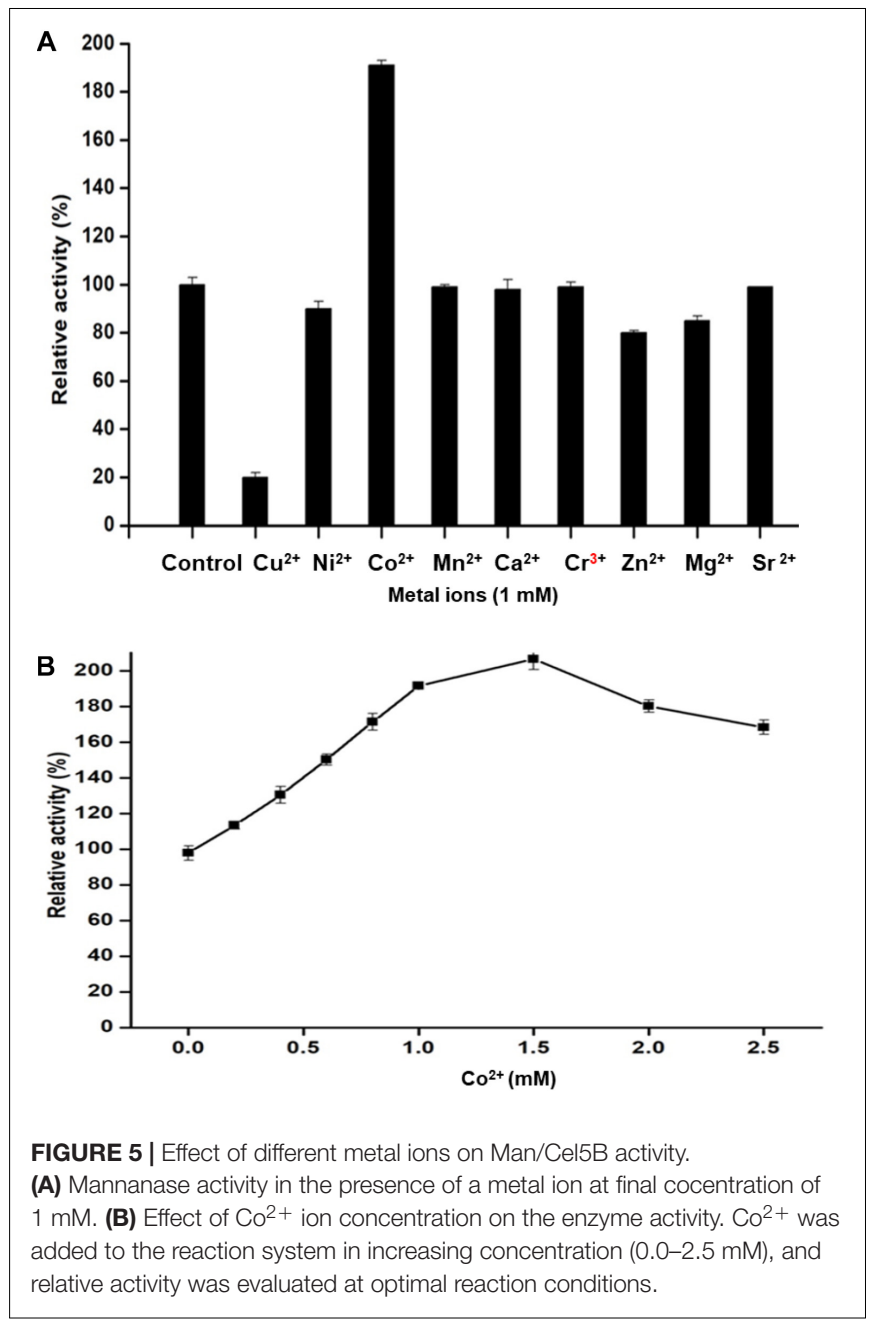

\section{DISCUSSION}

Among all the thermophilic sequences currently available, the genomic sequence of Tma encodes highest (7\%) number of glycosyl hydrolases. Nevertheless, many of these putative glycosyl hydrolases have not been further characterized. TM1752 gene from Tma encodes putative endoglucanase named as Cel5B. In this study, we report that TM1752 encodes for a novel bifunctional enzyme which can degrade mannan and cellulose with the highest activity for mannan. In substrate specificity assay, many enzymes are found to have a low activity on some other substrates with structures close to their preferred substrates. However, in the work reported here, the enzyme produced from the cellulase gene TM1752 has been found to use natural galactomannan as a main substrate, and therefore to have a mannanase activity much higher than its cellulase activity. These findings not only reveal a hyperthermophilic enzyme with the highest mannanase activity (Table 3), but also offer a bifunctional enzyme that is highly active to both mannan and cellulose (Table 1), which is potentially applied to an effective degradation of lignocellulosic biomass.

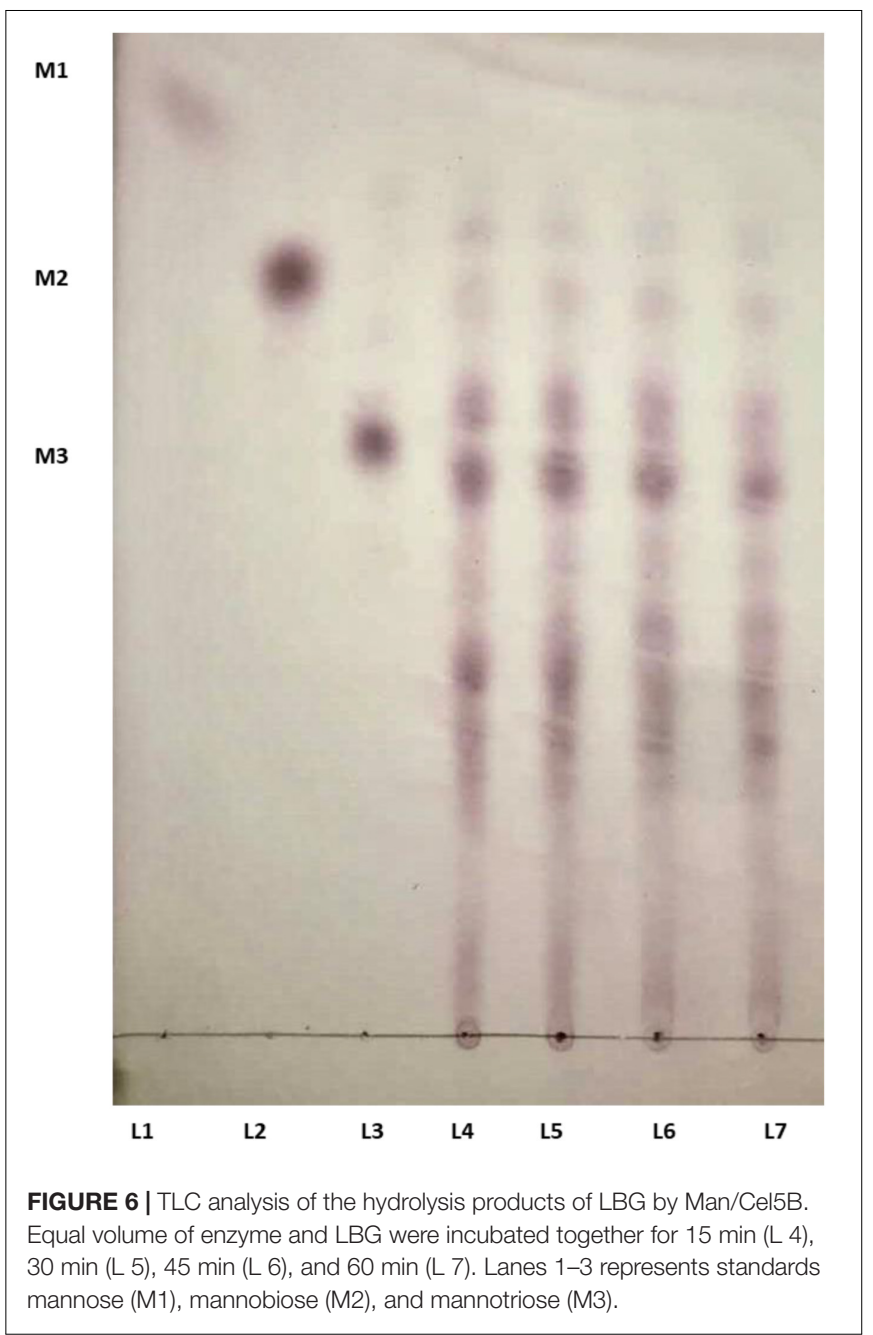

Hyperthermophilic enzymes have been found to be produced at very low levels, or to form inclusion bodies at large extent, only a small proportion of these enzymes are soluble and active (Yu et al., 2016). In the present study, pHsh vector was used for the expression of TM1752 gene in E. coli. pHsh utilizes a heat shock (Hsh) promoter for controlling the inserted gene, where alternative $\sigma^{32}$ regulates the gene expression. This plasmid is thought to have a high copy number of approximately 200 in host E. coli, and an upsurge in the temperature causes a swift increase of $\sigma^{32}$ which causes immediate expression of the target gene (TM 1752 in this case). A large number of chaperon proteins are also synthesized in E. coli, which increase the chance for the soluble expression of protein (Sha et al., 2020).

The substrate specificity of the purified enzyme depicts its dual nature as the enzyme could degrade both LBG and CMC. However, the mannanase activity was two-fold higher than its cellulase activity on CMC, and four-fold higher than the highest activity reported earlier for mannanase from Tma on galactomannan (Chhabra et al., 2002). The paired activity for both glucan- and mannan-based polysaccharides is a rare phenomenon for enzymes belonging to GH5 family, however 
there are few reports where $\beta$-mannanase has been found to degrade cellulose as well such as, Cel5A encoded by TM1751 gene of Tma (Chhabra et al., 2002), DturCelA and DturCelB of Dictyoglomus turgidum (Brumm et al., 2011; Fusco et al., 2018). According to Pereira et al. (2010), the structural analysis of cellulases and mannanases belonging to GH5 family revealed similarity in the active sites of both enzymes, which could be responsible for bifunctional nature of these enzymes. The structural analysis of GH5 cellulases and GH5 mannanases have revealed that the catalytic clefts of these enzymes use same active sites for hydrolysis of cellulose and mannan, respectively. The active sites of these enzymes contain two conserved glutamate residues that act as acid/base and nucleophile during hydrolysis of the substrate (Sakon et al., 1996; Hilge et al., 1998). The 3D structure of Man/Cel5B has been resolved, and deposited in protein data base bank (PDB code 1vjz) (Data not published), which revealed that Glu 139 and Glu 259 are used as active site residues for the hydrolysis of substrate by this enzyme. The similarity in the active sites of GH5 cellulases and GH5 mannanases could be a possible reason for the dual nature of Man/Cel5B. However, to gain the indepth knowledge of dual substrate recognition mechanism, the cellulose and mannan bound crystal structure of Man/Cel5B should be compared with apoenzyme in future. This will be helpful in the functional improvement of Man/Cel5B and other enzymes by protein engineering. The excellence to degrade both mannan and cellulose may play a significant role in the complete degradation of complex lignocellulosic material for subsequent biofuel production. Furthermore, the specific activity of most of the earlier-reported hyperthermophilic GH5 mannanases was much lower than that of $\beta$-mannanase reported in the current study (Table 3). $\beta$-mannanases from Phialophora sp. P13 (Zhao et al., 2010) and Bacillus subtilis YH12 (Liu et al., 2015) have higher specific activity of 851 and $7302 \mathrm{U} / \mathrm{mg}$, respectively for LBG, however, the optimum temperature of these enzymes is quite low compared with that of Man/Cel5B. The high specific activity and high thermotolerance of Man/Cel5B makes it an excellent candidate for industrial applications.

The optimum temperature of $\mathrm{Man} / \operatorname{Cel} 5 \mathrm{~B}\left(85^{\circ} \mathrm{C}\right)$ is higher than those of most $\beta$-mannanases that typically have optimum temperature between 45 and $75^{\circ} \mathrm{C}$ (Luo et al., 2017). Though, the $\beta$-mannanase from Tma (TM1227) (Chhabra et al., 2002) and Thermotoga neapolitana (McCutchen et al., 1996) have slightly higher optimal temperatures of 90 and $91^{\circ} \mathrm{C}$, respectively. However, the specific activity of these enzymes is very low (90 and $55 \mathrm{U} / \mathrm{mg}$, respectively) compared with that of Man/Cel5B (416 U/mg). A sudden decrease in enzyme activity was observed at $90^{\circ} \mathrm{C}$ which is thought to be because of denaturation of the protein at higher temperature (Dar et al., 2019). One of the important characteristics of Man/Cel5B is its longstanding thermostability which is higher than most of thermophilic and hyperthermophilic $\beta$-mannanases belonging of GH5. Thermostability was only comparable to Tma (TM1227) which lost almost $50 \%$ of the initial activity after $3 \mathrm{~h}$ of incubation at $90^{\circ} \mathrm{C}$ (Chhabra et al., 2002). $\beta$-mannanase from T. neapolitana has been reported to retain $50 \%$ of the initial activity at $91^{\circ} \mathrm{C}$ after $13 \mathrm{~h}$ of incubation (McCutchen et al., 1996). However, the gene encoding this protein has not been annotated to date. The optimum $\mathrm{pH}$ for Man/Cel5B was found to be in acidic range which is similar to that for $\beta$-mannanase (DturCelB) from D. turgidum (Fusco et al., 2018). However, the optimum $\mathrm{pH}$ for $\beta$-mannanase from Tma TM1227 is $\mathrm{pH} 7.1$ (Chhabra et al., 2002), which shows the optimum $\mathrm{pH}$ of $\beta$-mannanase is not species-specific.

The activity of Man/Cel5B was stable in the presence of most of the tested chemicals and detergents. Interestingly, Man/Cel5B

TABLE 3 | A comparison of properties of Man/Cel5B with some previously reported thermophilic and hyperthermophilic GH $5 \beta$-mannanases.

\begin{tabular}{|c|c|c|c|c|c|c|c|}
\hline Organism/gene & $\begin{array}{l}\text { Temperature } \\
\text { optimum }\left({ }^{\circ} \mathrm{C}\right)\end{array}$ & pH optimum & $\begin{array}{c}\text { Temperature and } \\
\text { pH stability }\end{array}$ & $\mathrm{K}_{m}$ value $\mathrm{mg} / \mathrm{ml}$ & $\begin{array}{l}\text { Specific activity } \\
\text { (U/mg) }\end{array}$ & $\begin{array}{l}\text { Molecular mass } \\
\quad(\mathrm{kDa})\end{array}$ & References \\
\hline $\begin{array}{l}\text { Thermotoga } \\
\text { maritimaa }^{a} \\
\text { TM1752 }\end{array}$ & 85 & 5.5 & $5 \mathrm{~h} 85^{\circ} \mathrm{C}, 5-8$ & 4.5 & 416 & 38 & This study \\
\hline $\begin{array}{l}\text { T. neapolitana } \\
\text { TN5068 }\end{array}$ & 91 & 7.1 & $N G$ & $N G$ & 1.23 & 55 & $\begin{array}{c}\text { McCutchen et al., } \\
1996\end{array}$ \\
\hline $\begin{array}{l}\text { Dictyoglomus } \\
\text { turgidum }^{\text {a }}\end{array}$ & 70 & 5.4 & $2 \mathrm{~h} 70^{\circ} \mathrm{C}, 5-9$ & 4.70 & 216.96 & 40 & Fusco et al., 2018 \\
\hline $\begin{array}{l}\text { Phialophora sp. } \\
\text { P13 }\end{array}$ & 60 & 1.6 & $2 \mathrm{~h} 55^{\circ} \mathrm{C}, 1.5-7$ & 2.5 & 851 & 44.2 & Zhao et al., 2010 \\
\hline $\begin{array}{l}\text { Bacillus sp. } \\
\text { N16-5 }\end{array}$ & 70 & 9.5 & $2 \mathrm{~h} 60^{\circ} \mathrm{C}, 8.5-10$ & $N G$ & $N G$ & 50 & Zheng et al., 2016 \\
\hline
\end{tabular}

aMeans recombinant enzyme.

NG means not given. 
activity dramatically increased in the presence of Tween 80 , and this may be attributed to increased substrate stabilization and decreased enzyme immobilization (Kamande et al., 2000). The presence of EDTA had almost no effect which indicates that Man/Cel5B is not metalloenzyme. Similarly, EDTA displayed no effect on $\beta$-mannanase activity from Streptomyces sp. S27 (Shi et al., 2011) and for DturCelB (Fusco et al., 2018). However, there are many reports where $\beta$-mannanase activity was either reduced to greater extent or completely halted in the presence of EDTA (Liu et al., 2015; Regmi et al., 2016; Singh et al., 2019). In this study, only SDS and CTAB drastically inhibited enzyme activity. Because SDS and CTAB can alter the three-dimensional structure of enzymes and consequently inhibit their activity (Singh et al., 2019). Similar effects of these ionic detergents were also observed on DturCelB (Fusco et al., 2018). Nevertheless, the activities of $\beta$-mannanase from Bacillus sp. N16-5 (Zheng et al., 2016), and Bacillus sp. CSB39 (Regmi et al., 2016) were enhanced in the presence of SDS.

In agreement with the present results, $\beta$-mannanase from Phialophora sp. P13 (MAN5AP13) and Bacillus nealsonii PN11 also exhibited enhanced activity in the presence of $\mathrm{Co}^{2+}$ (Zhao et al., 2010; Chauhan et al., 2014). According to Andreini et al. (2008), metal ions enhance enzyme activity by assisting in the proper substrate binding at the active sites. The activity of Man/Cel5B started decreasing when the concentration of $\mathrm{Co}^{2+}$ exceeded $1.5 \mathrm{mM}$ in the reaction mixture. The decrease in the activity at higher concentration of $\mathrm{Co}^{2+}$ ion may be due to the toxicity effect on enzyme (Afkar et al., 2010). Among the tested chemicals, only $\mathrm{Cu}^{2+}$ decreased the enzyme activity dramatically. Our results are supported by the observations of Fusco et al. (2018), who reported that the activity of DturCelB was greatly reduced in the presence of $\mathrm{Cu}^{2+}$. Similar inferences have been proposed for MAN5AP13 (Zhao et al., 2010). The change in enzyme activity in the presence of ions may be due to an alteration in the net overall electric charge of the enzyme surface (Zheng et al., 2016). The $\mathrm{V}_{\max }$ for Man/Cel5B was much higher than the already reported thermostable $\beta$-mannanases, for example, $\mathrm{V}_{\text {max }}$ for $\beta$-mannanase from $D$. turgidum (Fusco et al., 2018) and Thermotoga petrophila (Santos et al., 2012) were 473.1 and $114 \mathrm{U} / \mathrm{mg}$, respectively.

The substrate binding mechanism and the end products produced by the degradation of mannan containing polysaccharides by $\beta$-mannanases vary to a large extent even within the same family (Katrolia et al., 2013). The extent of the substitution of galactose residues and the distribution of glucose residues on the main chain of the mannan backbone affects the pattern of hydrolysis of mannan polysaccharides (Katrolia et al., 2013). The majority of $\beta$-mannanases cleave the mannan polysaccharide into mannobiose and mannotriose, yet there are few reports where mannose is also produced. Man/Cel5B hydrolyzes LBG into mannobiose, mannotriose and MOS. This hydrolysis pattern of Man/Cel5B is also shared by mannanase from Cellulosimicrobium sp. HY-13 (Kim et al., 2011). However, those from Bacillus sp. N16-5 (Ma et al., 2004), and Streptomyces sp. CS428 (Pradeep et al., 2016) resulted in the formation of mannose and MOS. MOS have gained a lot of interest as prebiotics. Because MOS cannot be digested by gastric or pancreatic juice and are utilized by the gut microbial flora for the synthesis of short-chain fatty acids. These fatty acids promote the growth of beneficial gut flora and are also used as energy source by the host organism (Asano et al., 2003). In fact, gammanase and hemicel-mannanase (commercially available $\beta$-mannanase) are currently utilized as prebiotics in poultry feed to mitigate the immunogenic effect of mannan (Korver, 2006). Srivastava and Kapoor (2017) used MOS produced by hydrolysis of LBG from Streptomyces sp. CS428 to improve the growth of various Lactobacillus species (beneficial gut bacteria) and also food born pathogenic bacteria such as E. coli and Salmonella typhi. These results proposed that MOS enhances the growth of Lactobacillus species, whereas inhibited the growth of E. coli and S. typhi. $\beta$-mannanase can also be used in the preparation of instant coffee to degrade galactomannan (results in gel formation during freeze-drying) in liquid coffee. All these observations suggest that Man/Cel5B has a wide potential for application in the food and feed industries as prebiotic for the production of MOS.

\section{CONCLUSION}

In conclusion, TM1752 from Tma was cloned and overexpressed in $E$. coli and indentified to be bifunctional mannanase and cellulase (Man/Cel5B). The purified Man/Cel5B enzyme was optimally active at $85^{\circ} \mathrm{C}$ and $\mathrm{pH} 5.5$, and exhibited high specific activity $416 \mathrm{U} / \mathrm{mg}$ for LBG, which is the highest among those of the hyperthermophilic mannanases reported earlier. In addition, Man/Cel5B displayed high thermal and $\mathrm{pH}$ stability, and could efficiently degrade LBG into mannobiose, mannotriose and MOS. All these properties make Man/Cel5B an excellent candidate for future food/feed and biofuel industries.

\section{DATA AVAILABILITY STATEMENT}

The original contributions presented in the study are included in the article/supplementary material, further inquiries can be directed to the corresponding author/s.

\section{AUTHOR CONTRIBUTIONS}

WS and CS comprehended and designed the experiments. BS and WZ performed the experiments. BS and PR analyzed the data. BS, CS, HW, and WS wrote and revised the manuscript. All authors contributed to the article and approved the submitted version.

\section{FUNDING}

This work was supported by the National Natural Science Foundation of China (Grant No. 31770089) and Advanced Talent Research Fund Project of Jiangsu University (16JDG031). 


\section{REFERENCES}

Afkar, E., Ababna, H., and Fathi, A. (2010). Toxicological response of the green alga Chlorella vulgaris, to some heavy metals. Am. J. Environ. Sci. 6, 230-237. doi: 10.3844/ajessp.2010.230.237

Akram, F., Ul Haq, I., Imran, W., and Mukhtar, H. (2018). Insight perspectives of thermostable endoglucanases for bioethanol production: a review. Renew. Energy 122, 225-238. doi: 10.1016/j.renene.2018.01.095

Andreini, C., Bertini, I., Cavallaro, G., Holliday, G. L., and Thornton, J. M. (2008). Metal ions in biological catalysis: from enzyme databases to general principles. J. Biol. Inorg. Chem. 13, 1205-1218. doi: 10.1007/s00775-008-0404-5

Arora, R., Behera, S., and Kumar, S. (2015). Bioprospecting thermophilic/thermotolerant microbes for production of lignocellulosic ethanol: a future perspective. Renew. Sustain. Energy Rev. 51, 699-717. doi: 10.1016/j.rser.2015.06.050

Asano, I., Hamaguchi, K., Fujii, S., and Iino, H. (2003). In vitro digestibility and fermentation of mannooligosaccharides from coffee mannan. Food Sci. Technol. Res. 9, 62-66. doi: 10.3136/fstr.9.62

Bounias, M. (1980). N-(1-Naphthyl) ethylenediamine dihydrochloride as a new reagent for nanomole quantification of sugars on thin-layer plates by a mathematical calibration process. Anal. Biochem. 106, 291-295. doi: 10.1016/ 0003-2697(80)90523-0

Brumm, P., Hermanson, S., Hochstein, B., Boyum, J., Hermersmann, N., Gowda, K., et al. (2011). Mining Dictyoglomus turgidum for enzymatically active carbohydrases. Appl. Biochem. Biotechnol. 163, 205-214. doi: 10.1007/s12010010-9029-6

Cerveró, J. M., Skovgaard, P. A., Felby, C., Sørensen, H. R., and Jørgensen, H. (2010). Enzymatic hydrolysis and fermentation of palm kernel press cake for production of bioethanol. Enzyme Microbial Technol. 46, 177-184. doi: 10.1016/ j.enzmictec.2009.10.012

Chauhan, P. S., Sharma, P., Puri, N., and Gupta, N. (2014). Purification and characterization of an alkali-thermostable $\beta$-mannanase from Bacillus nealsonii PN-11 and its application in mannooligosaccharides preparation having prebiotic potential. Biotechnology 238, 927-936. doi: 10.1007/s00217-014-2170-7

Chhabra, S. R., Shockley, K. R., Ward, D. E., and Kelly, R. M. (2002). Regulation of endo-acting glycosyl hydrolases in the hyperthermophilic bacterium Thermotoga maritima grown on glucan-and mannanbased polysaccharides. Appl. Environ. Microbiol. 68, 545-554. doi: 10.1128/AEM.68.2.545-554.2002

Dar, M. A., Pawar, K. D., Rajput, B. P., Rahi, P., and Pandit, R. S. (2019). Purification of a cellulase from cellulolytic gut bacterium, Bacillus tequilensis G9 and its evaluation for valorization of agro-wastes into added value byproducts. Biocatal. Agricul. Biotechnol. 20, 101-219. doi: 10.1016/j.bcab.2019.101219

Dhawan, S., Singh, R., Kaur, R., and Kaur, J. (2016). A $\beta$-mannanase from Paenibacillus sp.: optimization of production and its possible prebiotic potential. Biotechnol. Appl. Biochem. 63, 669-678. doi: 10.1002/bab.1419

Ebaid, R., Wang, H., Sha, C., Abomohra, A. E.-F., and Shao, W. (2019). Recent trends in hyperthermophilic enzymes production and future perspectives for biofuel industry: a critical review. J. Clean. Prod. 238:117925. doi: 10.1016/j. jclepro.2019.117925

Fusco, F. A., Ronca, R., Fiorentino, G., Pedone, E., Contursi, P., Bartolucci, S., et al. (2018). Biochemical characterization of a thermostable endomannanase/endoglucanase from Dictyoglomus turgidum. Extremophiles 22, 131-140. doi: 10.1007/s00792-017-0983-6

Ghosh, A., Luís, A. S., Brás, J. L., Fontes, C. M., and Goyal, A. (2013). Thermostable recombinant $B-(1 \rightarrow 4)$-mannanase from $C$. thermocellum : biochemical characterization and manno-oligosaccharides production. J. Agric. Food Chem. 61, 12333-12344. doi: 10.1021/jf403111g

Hilge, M., Gloor, S. M., Rypniewski, W., Sauer, O., Heightman, T. D., Zimmermann, W., et al. (1998). High-resolution native and complex structures of thermostable $\beta$-mannanase from Thermomonospora fusca - substrate specificity in glycosyl hydrolase family 5. Struct. Struct. 6, 1433-1444. doi: 10.1016/S0969-2126(98)00142-147

Jiang, Z., Wei, Y., Li, D., Li, L., Chai, P., and Kusakabe, I. (2006). High-level production, purification and characterization of a thermostable $\beta$-mannanase from the newly isolated Bacillus subtilis WY34. Carbohydrate Pol. 66, 88-96. doi: 10.1016/j.carbpol.2006.02.030
Kaira, G. S., Panwar, D., and Kapoor, M. (2016). Recombinant endo-mannanase (ManB-1601) production using agro-industrial residues: development of economical medium and application in oil extraction from copra. Int. J. Biol. Macromol. 133, 220-227. doi: 10.1016/j.biortech.2016.02.133

Kamande, G., Baah, J., Cheng, K.-J., Mcallister, T., and Shelford, J. A. (2000). Effects of Tween 60 and Tween 80 on protease activity, thiol group reactivity, protein adsorption, and cellulose degradation by rumen microbial enzymes. J. Dairy Sci. 83, 536-542. doi: 10.3168/jds.S0022-0302(00)74913-7

Katrolia, P., Yan, Q., Zhang, P., Zhou, P., Yang, S., and Jiang, Z. J. (2013). Gene cloning and enzymatic characterization of an alkali-tolerant endo-1, 4$\beta$-mannanase from Rhizomucor miehei. J. Agric. Food Chem. 61, 394-401. doi: $10.1021 /$ jf303319h

Katsimpouras, C., Dimarogona, M., Petropoulos, P., Christakopoulos, P., and Topakas, E. (2016). A thermostable GH26 endo- $\beta$-mannanase from Myceliophthora thermophila capable of enhancing lignocellulose degradation. Appl. Microbiol. Biotechnol. 100, 8385-8397. doi: 10.1007/s00253-016-7609-2

Kim, Y. K., Ham, S.-J., Lee, H. J., Cho, H.-Y., Kim, J.-H., Kim, Y.-J., et al. (2011). Cloning and characterization of a modular GH5 $\beta$-1, 4-mannanase with high specific activity from the fibrolytic bacterium Cellulosimicrobium sp. strain HY-13. Bioresource Technol. 102, 9185-9192. doi: 10.1016/j.biortech.2011.06. 073

Korver, D. R. (2006). Overview of the immune dynamics of the digestive system. J. Appl. Poult. Res. 15, 123-135. doi: 10.1093/japr/15.1.123

Lever, M. (1972). A new reaction for colorimetric determination of carbohydrates. Anal. Chem. 47, 273-279. doi: 10.1016/0003-2697

Li, J.-M., and Nie, S.-P. (2016). The functional and nutritional aspects of hydrocolloids in foods. Food Hydrocolloids 53, 46-61. doi: 10.1016/j.foodhyd. 2015.01.035

Liu, H.-X., Gong, J.-S., Li, H., Lu, Z.-M., Li, H., Qian, J.-Y., et al. (2015). Biochemical characterization and cloning of an endo-1,4- $\beta$-mannanase from Bacillus subtilis YH12 with unusually broad substrate profile. Process Biochem. 50, 712-721. doi: 10.1016/j.procbio.2015.02.011

Liu, W., Tu, T., Ga, Y., Wang, Y., Zheng, F., Zheng, J., et al. (2019). Insight into the thermophilic mechanism of a glycoside hydrolase Family $5 \beta$-mannanase. J. Agric. Food Chem. 67, 473-483. doi: 10.1021/acs.jafc.8b04860

Luo, Z., Miao, J., Li, G., Du, Y., and Yu, X. (2017). A recombinant highly thermostable $\beta$-mannanase (ReTMan26) from thermophilic Bacillus subtilis (TBS2) expressed in Pichia pastoris and its $\mathrm{pH}$ and temperature stability. Appl. Biochem. Biotechnol. 182, 1259-1275. doi: 10.1007/s12010-0172397-4

Ma, Y., Xue, Y., Dou, Y., Xu, Z., Tao, W., and Zhou, P. (2004). Characterization and gene cloning of a novel $\beta$-mannanase from alkaliphilic Bacillus sp. N16-5. Extremophiles 8, 447-454. doi: 10.1007/s00792-004-0405-4

McCutchen, C. M., Duffaud, G. D., Leduc, P., Petersen, A. R., Tayal, A., Khan, S. A., et al. (1996). Characterization of extremely thermostable enzymatic breakers $(\alpha-1,6$-galactosidase and $\beta$-1, 4-mannanase) from the hyperthermophilic bacterium Thermotoga neapolitana 5068 for hydrolysis of guar gum. Biotechnol. Bioeng. 52, 332-339. doi: 10.1002/(sici)1097-0290(19961020)52:2<332::aidbit13>3.0.co;2-1

Myung, S., Wang, Y., and Zhang, Y.-H. P. (2010). Fructose-1, 6-bisphosphatase from a hyper-thermophilic bacterium Thermotoga maritima: characterization, metabolite stability, and its implications. 45. Process Biochem. 45, 1882-1887. doi: 10.1016/j.procbio.2010.03.017

Niu, C., Zhu, L., Xu, X., and Li, Q. (2017). Rational design of thermostability in bacterial 1, 3-1, 4- $\beta$-glucanases through spatial compartmentalization of mutational hotspots. Appl. Microbiol. Biotechnol. 101, 1085-1097. doi: 10.1007/ s00253-016-7826-8

Pereira, J. H., Chen, Z., Mcandrew, R. P., Sapra, R., Chhabra, S. R., Sale, K. L., et al. (2010). Biochemical characterization and crystal structure of endoglucanase Cel5A from the hyperthermophilic Thermotoga maritima. J. Struct. Biol. 172, 372-379. doi: 10.1016/j.jsb.2010.06.018

Pradeep, G., Cho, S. S., Choi, Y. H., Choi, Y. S., Jee, J.-P., Seong, C. N., et al. (2016). An extremely alkaline mannanase from Streptomyces sp. CS428 hydrolyzes galactomannan producing series of mannooligosaccharides. World J. Microbiol. Biotechnol. 32:84. doi: 10.1007/s11274-0162040-5

Regmi, S., Pradeep, G., Choi, Y. H., Choi, Y. S., Choi, J. E., Cho, S. S., et al. (2016). A multi-tolerant low molecular weight mannanase from Bacillus sp. CSB39 and 
its compatibility as an industrial biocatalyst. World J. Microbiol. Biotechnol. . 92, 76-85. doi: 10.1016/j.enzmictec.2016.06.018

Sakon, J., Adney, W. S., Himmel, M. E., Thomas, S. R., and Karplus, P. A. (1996). Crystal structure of thermostable family 5 endocellulase E1 from Acidothermus cellulolyticus in complex with cellotetraose. Biochemistry 35, 10648-10660. doi: 10.1021/bi9604439

Santos, C. R. D., Paiva, J. H., Meza, A. N., Cota, J., Alvarez, T. M., Ruller, R., et al. (2012). Molecular insights into substrate specificity and thermal stability of a bacterial GH5-CBM27 endo-1,4- $\beta$-d-mannanase. J. Struct. Biol. 177, 469-476. doi: 10.1016/j.jsb.2011.11.021

Sarmiento, F., Peralta, R., and Blamey, J. M. (2015). Cold and hot extremozymes: industrial relevance and current trends. Front. Bioeng. Biotechnol. 3:148. doi: 10.3389/fbioe.2015.00148

Sha, C., Sadaqat, B., Wang, H., Guo, X., and Shao, W. (2020). Efficient xylanto-sugar biotransformation using an engineered xylanase in hyperthermic environment. Int. J. Biol. Macromol. 157, 17-23. doi: 10.1016/j.ijbiomac.2020. 04.145

Shi, P., Yuan, T., Zhao, J., Huang, H., Luo, H., Meng, K., et al. (2011). Genetic and biochemical characterization of a protease-resistant mesophilic $\beta$-mannanase from Streptomyces sp. S27. J. Ind. Microbiol. Biotechnol. 38, 451-458. doi: 10. 1007/s10295-010-0789-3

Shukor, H., Abdeshahian, P., Al-Shorgani, N. K. N., Hamid, A. A., Rahman, N. A., and Kalil, M. S. J. B. T. (2016). Enhanced mannanderived fermentable sugars of palm kernel cake by mannanase-catalyzed hydrolysis for production of biobutanol. Bioresour. Technol. 218, 257-264. doi: 10.1016/j.biortech.2016.06.084

Singh, S., Singh, G., Khatri, M., Kaur, A., and Arya, S. K. (2019). Thermo and alkali stable $\beta$-mannanase: characterization and application for removal of food (mannans based) stain. Int. J. Biol. Macromol. 134, 536-546. doi: 10.1016/j. ijbiomac.2019.05.067

Srivastava, P. K., and Kapoor, M. J. B. A. (2017). Production, properties, and applications of endo- $\beta$-mannanases. Biotechnol. Adv. 35, 1-19. doi: 10.1016/j. biotechadv.2016.11.001
Yanan, L., Yang, P., Meng, K., Wang, Y., Luo, H., Wu, N., et al. (2008). Gene cloning, expression, and characterization of a novel $\beta$-Mannanase from Bacillus circulans CGMCC 1416. J. Microbiol. Biotechnol. 18, 160-166. doi: 10.1002/bab. 1510

Yu, T., Anbarasan, S., Wang, Y., Telli, K., Aslan, A. S., Su, Z., et al. (2016). Hyperthermostable Thermotoga maritima xylanase XYN10B shows high activity at high temperatures in the presence of biomass-dissolving hydrophilic ionic liquids. Extremophiles 20, 515-524. doi: 10.1007/s00792-0160841-y

Zhao, J., Shi, P., Luo, H., Yang, P., Zhao, H., Bai, Y., et al. (2010). An acidophilic and acid-stable $\beta$-mannanase from Phialophora sp. P13 with high mannan hydrolysis activity under simulated gastric conditions. J. Agric. Food Chem. 58, 3184-3190. doi: 10.1021/jf904367r

Zheng, H., Yu, Z., Fu, X., Li, S., Xu, J., Song, H., et al. (2016). High level extracellular production of a truncated alkaline $\beta$-mannanase from alkaliphilic Bacillus sp. N16-5 in Escherichia coli by the optimization of induction condition and fedbatch fermentation. J. Ind. Microbiol. Biotechnol. 43, 977-987. doi: 10.1007/ s10295-016-1773-3

Zhu, M., Zhang, L., Yang, F., Cha, Y., Li, S., Zhuo, M., et al. (2020). A recombinant $\beta$-Mannanase from Thermoanaerobacterium aotearoense SCUT27: biochemical characterization, and its thermostability improvement. J. Agric. Food Chem. 68, 818-825. doi: 10.1021/acs.jafc.9b06246

Conflict of Interest: The authors declare that the research was conducted in the absence of any commercial or financial relationships that could be construed as a potential conflict of interest.

Copyright (c) 2021 Sadaqat, Sha, Rupani, Wang, Zuo and Shao. This is an open-access article distributed under the terms of the Creative Commons Attribution License (CC BY). The use, distribution or reproduction in other forums is permitted, provided the original author(s) and the copyright owner(s) are credited and that the original publication in this journal is cited, in accordance with accepted academic practice. No use, distribution or reproduction is permitted which does not comply with these terms. 